\title{
Ecological planning as an inner-city revitalisation agenda for Harare, Zimbabwe
}

\author{
Abraham Matamanda ${ }^{1}$ and Innocent Chirisa ${ }^{2^{*}}$
}

\begin{abstract}
Background: This article examines approaches for integrating ecological thought in inner-city revitalisation with a special focus on the inner-city of Harare. It is an exploration and possible (re-)framing of the garden suburb approach that is strongly rooted in the garden city concept with the aim of enabling the attainment of the City of Harare Vision 2025 that the city leaders and managers have envisioned.

Methods: The methods used to collect data included key informant interviews, field surveys and in depth analysis of secondary sources.

Results: Past initiatives in seeking to transform the inner-city of Harare into a vibrant environment proved futile with little effect on the face lifting of the critical space. This is partly because just socio-economic planning approaches were adopted.

Conclusions: The article concludes that the absence of ecological planning among other factors of finance and political will explain the non-effect of past revitalisation of the inner-city of Harare. Given this explanation, we suggest sustained inner-city revitalisation that conforms ecological planning to the city's 2025 vision and beyond.
\end{abstract}

Keywords: Ecological planning; Indicative planning; Inner-city revitalisation; Garden city; Urban sustainability

\section{Introduction}

In urban ecosystems, human and natural processes are closely entwined. This makes it necessary to recognise the city as an ecosystem that has a wide range of processes and organisms within it. In UN-HABITAT (2010) it is noted that people, air, soil and water are some of the organisms that exist in the city's ecosystem. Instead of focusing on certain dimensions of the cities only, it is advisable to consider all the aspects of the city from social to ecological processes as these are inter alia and affect each other with the ecological contributing on the socio-economic negatively or positively. Steiner (2002) argues that such a consideration has the ability to reduce both social and ecological uncertainties and vulnerabilities. In short, ecological processes are present in cities hence the need to preserve and promote such basic biological processes upon which human health and wellbeing depend. Therefore, ecological planning becomes

\footnotetext{
* Correspondence: chirisa.innocent@gmail.com

${ }^{2}$ Department of Rural \& Urban Planning, University of Zimbabwe, PO Box MP167, Mt Pleasant, Harare, Zimbabwe

Full list of author information is available at the end of the article
}

the panacea to provide creative new ways to insinuate ecological processes in cities (Felson and Pickett 2005).

Traditional approaches to inner-city revitalisation have focused more on socio-economic and political aspects (Chirisa 2010; Bright 2000; Latham 2000; Ross and Leigh 2000). This has proved riddled with a plethora of limitations hence the practice has not always spelt out a successful story. The industrial revolution in the $18^{\text {th }}$ century marked the inception of a rapid global urbanisation trend that has persisted to this day (UN-HABITAT 2009). Industrial pollution coupled with human manipulation of the natural ecosystem has been key drivers of environmental degradation in cities that has resulted in a compromise of the quality of the natural ecosystem. Effluent from industries and residential areas is discharged into rivers or on the surface in some cases as noted by Hardoy et al. (1993). The atmosphere is continuously polluted with gaseous emissions and natural vegetation removed to pave way for infrastructure development and other economic activities (WHO 2002). Williams (2000) asserts to this point in that the magnitude of urban population growth in developing countries is a direct indicator 
of the degree of spatial concentration of people, industries, commerce, vehicles, energy consumption, water use, waste generation, and other environmental stresses. He further notes that it is the desire to attain economic development that exacerbates these environmental problems. Planning seems to focus a blind eye on the natural environment yet this is an intrinsic building block to the city system if sustained city revitalization is to ensure. In spite of planning processes undertaken in the the contemporary city, events on the ground do not often translate into a successful story. Developers prefer sites in the city outskirts as these are more lucrative and attract people who prefer a natural environment rather than a wholly built one since the former is more refreshing space than the latter. In order to redress these environmental ills at the global level, there have been calls to reconsider the natural environment and try to bring qualities of the countryside in the city (UNEP 2007). At the national level in Zimbabwe, it seems little is being done in terms of ecological planning in urban areas. The Short Term Emergency Recovery Programme (STERP) of March 2009 formulated by the government of Zimbabwe dwells much on rural areas, conservation of natural resources while placing little emphasis on the nexus between urban infrastructure development and natural environment (Government of Zimbabwe 2009). Likewise, Zimbabwe Agenda for Sustainable Socio-Economic Transformation (ZIMASSET) document echoes the same sentiments, environmental discussions in urban areas are cited in relation to energy use. There is an urge to use solar energy for lighting and heating (Government of Zimbabwe 2013) which culminates into environmental lighting. However, with the rapid urbanisation process in the country, it is imminent to reconsider the planning ideals for the cities. It is crucial to consider the existence of the natural environment in urban areas as well rather than the rural areas only. A good number of questions though, remain unanswered, for example, why has revitalisation plans worked in some cities and not in others? How can cities enhance sustained development to propel investment especially in the inner cities through revitalisation plans?

We ask the same questions with the proposed revitalisation efforts in the inner-city of Harare, the capital city of Zimbabwe seeking to attain an excellent city status as stipulated in its Vision 2025 document (City of Harare 2012). One major aspect articulated in this document is to apply an ecological planning thrust, which has been conspicuous by its absence in the previous efforts to do the same. It is imperative now to explore and possibly (re-)frame the garden suburb approach, strongly rooted in the garden city concept to enable the attainment of the City of Harare Vision 2025 that the city leaders and managers have envisioned. This article examines approaches adoptable in a quest to integrate ecological thought in inner-city revitalisation focusing on the inner-city of Harare. The major focus of the article is to proffer an exploration of how ecological planning can be integrated into the realm of inner-city revitalisation. Based on this philosophy, the article argues that Harare's pursuits of a sustained outcome will eliminate the prevailing socioeconomic and environmental ills currently bedevilling the area. The methods used to collect data to enable the writing of this article included key informant interviews, ground observations and in depth analysis of secondary sources including strategic, master and local plans as well as reports and minutes of meetings. An intense literature search was done to obtain the crucial information to broaden the knowledge and get a deeper understanding of ecological planning in relation to inner-city revitalisation in Harare. Specifically, the key documents reviewed included operational development plans of the City of Harare with the Local Development Plan No 17 and city's strategic plan 2012-2025 being the main data sources. Key informant interviews were for Harare City officials to establish and explore on the approaches, methods and theories used in the revitalisation efforts of the inner-city of Harare. Field surveys involved some on-site observations of the conditions and use of buildings and the environmental state in the area because of the revitalisation initiatives. The study makes use of document analysis as this has enabled the understanding of the planning philosophy previously adopted for the city. From the documents the gaps were identified which prompted the recommendation of an ecological planning approach that seem to be the missing bloc in the revitalisation maze for the inner city in Harare. The article is organised under the following subheadings: introduction, context of the study, ecological planning in inner-city revitalisation: a review, initiatives in Harare inner-city revitalisation and the last part of the article proffers a discussion and way forward to crystallise the debate to foster recommendations that can work for the city of Harare.

\section{Ecological planning and inner-city revitalisation: a review}

Cities are (and have been) the major sources of carbon emission. The industrial activities undertaken in these important geographical spaces are the reason for the 'brown' development that characterise many urban areas globally, today. In trying to redress this 'brown development effect', recently, there has been call for low carbon cities. Low carbon cities are those cities that are selfcleansing or have low emission of carbon. The most practical way to attain this is through the greening of the cities (Hammer et al. 2011; UNEP 2007; NicholsonLord 2003) and this concept is widely advocated for at the global level for cities to be ranked as world class. It 
is clear that efforts at the global scale are all aimed at upholding a self-sustaining and ecologically functional city that affects positively on the natural environment (Hutchings 2011; Freestone 2006). The rapid urbanisation especially in Africa has placed much strain on the cities. The growing urban populace has resulted in cities being greatly compromised and exploited to unimagined levels (UN-HABITAT 2010). The urbanisation process has therefore compromised urban space. It can be noted that most of the natural resources have been removed and this is coupled with various anthropogenic activities, which increase the greenhouse gas emissions. Beyond any reasonable doubt, there is a dire need to rethink the innercity revitalisation and consider approaches that lead to sustainable development in cities, embrace green agenda and are low in carbon emission. Nevertheless, inner-city revitalisation is a daunting task. According to Zielenbach (2000), it has no clear-cut procedure or roadmap to success. In this regard, various approaches and methods are critical for use.

Economic development and urbanisation processes that ignore the existence of the natural environment are bound to be marred with a lot of shortfalls as it impinges on the ecological processes due to negative externalities such as air pollution among others. There is no better way to redress this quagmire other than rethinking ecological planning which attempts to combine the socio-economic and environmental factors in space so as to come up with a benign plan that culminates into sustainable development without jeopardising any element in the way. Ecological planning therefore is a new paradigm that promotes economic development while reducing environmental degradation and preserving the natural resource in the city. McHarg (1981) defines ecological planning as a comprehensive, holistic and interdisciplinary approach to land, air and water use planning that is aimed at promoting health, safety and amenity in the cities. Williams (2000) notes that ecological planning is an approach to planning that begins with an ecologically-bounded area, stresses the integration of social, economic and environmental factors seeks, to involve all the relevant interests and power-holders in identifying desirable futures, evaluating alternative pathways and implementing preferred solutions. Williams (2000) has further argued that ecological planning is based on some principles, which include the following:

- The need for planning units based on natural boundaries and reflecting ecological functions while replacing a politically oriented hierarchy of units.

- Ecological planning designs with nature and respect human activity and its effect on the environment as well as the limits of resource availability and ecosystem resilience.
Planning and the political sphere cannot be separated as Williams (2000) notes that successful ecological planning ought to consider the political hierarchy in the area and ensure that the planning process is also politically oriented. Politics is so rife in inner cities to an extent that planning effort may be fruitless is the notion of politics is not embraced in planning. Since ecological planning taps on this, it surely calls for some consideration in attempts to revitalise inner cities especially considering the urban context which is largely influenced by local politics in the allocation and accessibility to resources. Rusong (1996), pp. 25, argues “... workable ecological planning depends not only on the rationality of the planners but also on the participation of local citizens, entrepreneurs and decision-makers". Stakeholder participation therefore is the glue that binds ecological planning and is the sure way to its success. It is critical to consider and take into account the opinions of these stakeholders throughout the planning process. Ecological planning then is a concerted effort aimed at transforming the space into a functional component rather than a structural one and takes into account environmental, social, economic and political aspects and dynamics surrounding the planning space while upholding the local people's views and perceptions.

There have been recent efforts to protect and conserve the natural environment, globally. The Rio Summit in 1992 adopted the 1987 Brutland Commission's definition of sustainable development: the use of resources now without compromising use for future generations (WCED 1987). This is a futuristic concept that has come to be hailed the world over and has now been integrated into many development policies and plans (UN-HABITAT 2009; UNEP 2007). The concept is premised on three pillars of environment, society and economic development. The same pillars constitute ecological planning and it is interesting to note that ecological planning therefore has its roots embedded in the futuristic concept of sustainable development, which is the darling of most planners in recent times. Every city now strives to attain urban sustainability as a means of mitigating and preventing the environmental woes that result from rapid urbanisation. In The World Bank (2009), urban sustainability is referred to as sound urbanisation that is resource-conserving, environmentally friendly, economically efficient and socially harmonious. This would be the epitome of urbanisation as all the components of the city would be functional and working in harmony to uplift human livelihoods in the city. Ecological planning therefore seeks to combine various systems with the sole intention of attaining sustainable development. Sound planning considers the plight of the citizens who contribute meaningfully to the development initiatives in their respective localities. A consideration is also made of the social equity, which should be balanced with the 
environmental and economic functions in the area. Since ecological planning addresses these aspects, it is best suited for the revitalisation of the inner-city of Harare. Ecological planning assumes varying pathways each, which builds into this seemingly complex process, aimed at attaining urban sustainability.

Green agenda is one such initiative that forms a constituent to ecological planning as it focuses primarily on ecological problems and their solutions through an analysis of the environmental issues in the context of human society (Swilling, 2005). Kjellén and McGranahan (2006) add that green agenda focus on reducing indirect threats to human well-being by preventing resource degradation and the loss of natural life support systems. The green agenda is a development method that is premised on the notion of citizen participation and strives to bring a winwin situation for local sustainable development taking into account the local community values. The development approach encompasses three main aspects of community values rather than problems, full participation of all citizens that is not limited to specific stakeholders only and the result of a plan that is owned by the local community who could have immensely contributed to its formulation. The green agenda thus strives to achieve sustainable development in that the environmental, economic and social values of the community are communicated fully and this results in the formulation of a revitalisation plan that is premised on these values, thus sustaining revitalisation of inner cities. Bakker et al. (2005) argue that Green Agenda promotes the protection and conservation of basic living and environmental conditions as well as citizen participation. It is no doubt that green agenda concept comes with many benefits if adopted as a revitalisation option in that there is a strong bias toward the preservation of the natural environment and the inclusion of various stakeholders in the planning process cannot be rubbished. Overall, sustainable development with respect to inner-city revitalisation is muddled in conflict between upholding economic development and protecting the natural environment with equity being the holding force. Most city plans are failing because they are based on economic basis only with little regard for the natural environment. Yet, opportunities for the adoption of the Green Agenda are immense. City managers and planners of this century often use this concept in attempts to seek successful revitalisation of the inner city.

In recent times, there have been realisations for the need of a paradigm shift to include environmental issues in inner-city or city development and designs. It is interesting to note that current efforts to development cities in Africa are concentrated more on upholding a city that is environmental functional. UN-HABITAT and New Partnership for Development (NEPAD) have emerged as the key players in attempts to promote sustainable city development in the African context. NEPAD argues that sustainable development cannot be attained without sustainable urbanisation and this has been realized after a consideration of the chaotic urbanisation trend in Africa during the past decades. It is against this background that NEPAD introduced the NEPAD city that is defined as one that is functional, economically productive, socially inclusive, environmentally sound, safe, and healthy and secure (UN-HABITAT 2010).

The NEPAD City programme has aimed to support cities in that they have to play a positive role as engines for growth, building on poverty alleviation, empowering the municipalities while addressing environmental issues such as pollution, degradation and conserving environmental resources (UN-HABITAT 2009). There is great need to produce cities that are productive and inclusive and focus on the nexus between population, environment, urbanisation and cross cutting issues. Furthermore, attempts to create a sustainable city have to consider the four factors listed above though special emphasis has to be given to the environmental factor. In light of this, environmental issues are closely entwined in city development initiatives and are actually recognised as the cornerstone of any sustainable revitalisation plans. Campbell (1996) asserts that urban planning should be focused on sustainable development. The attainment of this is largely through balancing environmental, economic and social aspects of an area so that they exist in unison without gaps between them. Once the assumed conflicts are resolved, urban planning becomes a success. Ecological planning, therefore serves as the adherent to these three seemingly isolated yet intrinsic components of the urban setup. South Africa is a good example of a country that has been consistent in efforts to embrace these initiatives in their development pursuits. The city of Johannesburg (JDA undated) bears testimony to this as many development plans have been put in place to revitalise the run down inner cities. The city of Johannesburg has been renewed by EcoCity in partnership with the Johannesburg council have tackled poor environmental management in the inner-city by framing a public-private partnership that adopts ecological planning in the design and revitalisation of the inner-city that had decayed. Because of this ecological planning approach, there has been remarkable success in the revitalisation of the inner-city of Johannesburg. Similar blueprints seem to exist for the city of Harare, but only that the approaches they take appear to cast a blind eye on the ecological component of the city. If lessons are to be drawn from examples such as Johannesburg, more would be achieved as there has been a strong incline towards the ecological components that were capitalised upon. 
At the end of the $19^{\text {th }}$ century, England experienced massive rural-urban migration. The primary reason was the agricultural depression that plagued Britain at the time and the negative effects of this extempore urbanisation were structural unemployment, slum development and deterioration of physical infrastructure as well as that of the natural environment in the cities. Ultimately, the city lost its appealing statute together with all its glamour mostly due to the brown development that did not give credit to the externalities in the form of air pollution mostly from the industries in and around the city. Action to redress the ongoing physical decay became inevitable. There was a need for a planning approach that would revitalise the city and limit the carbon emission so that the city would be a healthy and aesthetically pleasing built environment. Ecological planning seemed to be the way forward in this instance and that is what Ebenezer Howard envisioned and conceptualised in his infamous Garden City idea that distilled in his 1902 book, Garden Cities of Tomorrow. Howard had a splendid vision in which he sought to transform the city into a liveable place by integrating qualities of the country in the city through parks, recreation grounds and allotment gardens, which were to substitute slums and the urban squalor prevailing in the city at the time (Howard, 1902). Industry was to be located on the periphery of the built-up area, encircled by a 'green girdle' of farmland. The population was limited to 32000 inhabitants and the garden city at 6000 acres with 1000 acres to be occupied by the city. According to Lethaby and Purdom (1921), a garden city is that town designed for industry, offering residents a healthy living, surrounded by a green belt with land under public ownership or being held in trust for the community. Thus, a garden city is one that is self-sustaining, has less industrial pollution and is socially inclusive (Howard 1902). Howard drew his inspiration from his assessment of the need to combine the city qualities such as employment and civilisation with those of the countryside (especially abundance of cheap land and natural beauty). The whole idea was to mitigate the disadvantages of both. A garden city thus matches the characteristics of a product of ecological planning in a number of ways. There are some similarities between the two, which are worth mentioning. Ecological planning strives to preserve and conserve the natural environment in ways that do not compromise human well-being or the built environment. Likewise, garden city is found upon the same principles as pointed out by White (1948) pp45 that "... the garden city concept wishes to preserve as much of the rural atmosphere as possible in an urban area by restricting densities, de-countenancing flat tenements and excluding non-residential, non-conformist buildings. It gives a great deal of private open space but it falls short of deliberate encouragement of planning for communal activities and of deepening the social bonds within the local community.' There is a close similarity between the two, which gives much credential to the garden city as a means to ecological planning. The garden city ideal came at a time when brown development had marred the whole city and the level of carbon emission was out of hand. This was a splendid idea that would transform the city into a liveable one with low carbon mainly due to the incorporation of the green girdle. This is the same concept upon which ecological planning is found.

Hutchings (2011) defines a garden suburb as a predominantly residential area (with businesses serving only the local population) located in the outer parts of a city or town. The approach is a piecemeal to the garden city and tries to adopt a systems approach to greening the city starting at a local level, and ultimately culminating into a grand plan that will transform the whole city. The essence of the garden suburb approach stems from garden city concept and wishes to transform the residential areas into country like environments that are more natural and self-cleansing (cf. Table 1.). The logic is a low carbon urban space that is aesthetically pleasing and will attract investment from middle residents as well as businesses thus increasing the land value of the area. Ecological planning can therefore be done according to stages and levels. It is not just a matter of a grand plan but initiatives can even start on a small scale or with various pockets, which would eventually intersect, with time into one single green city.

The place of inner-city revitalisation in urban sustainability Cities are engines of economic development in urban areas and their contribution to the sustainability of these

\section{Table 1 Objectives of revitalisation}

(a) Restructuring and re-planning designated target areas

(b) Designing more effective and environmentally-friendly local transport and road networks

(c) Rationalizing land uses

(d) Redeveloping dilapidated buildings into new buildings of modern standard and environmentally-friendly design

(e) Promoting the rehabilitation of buildings in need of repair

(f) Preserving buildings, sites and structures of historical, cultural or architectural interest

(g) Preserving as far as practicable local characteristics

(h) Preserving the social networks of the local community

(i) Providing purpose-built housing for groups with special needs, such as the elderly and the disabled

(j) Providing more open space and community/welfare facilities

(k) Enhancing the townscape with attractive landscape and urban design.

Source: Planning and Lands Bureau (2001). 
urban spaces cannot be underestimated. This economic factor has resulted in unprecedented urbanisation that has jeopardised and degraded the city physical and socio-economic outlook. The environment is very fragile and often suffers the aftermath of urbanisation. The natural environment is compromised largely. This has resulted in the deterioration of the urban space. Urban decay has therefore increased due to this fact as the urban space fails to contain the pressure exerted on the limited resources and services available. Efforts to address this ongoing deterioration of the inner cities and cities at large then become inevitable and many local authorities engage in revitalisation strategies to attain and/or maintain urban sustainability. Acioly (1999: 9) defines inner-city revitalisation as an approach to reverse on-going physical and social deterioration and economic decline that excludes urban areas and their inhabitants from the citywide urban development process. This definition considers inner-city revitalisation as a process aimed at advancing economic development in the city through the improvement of the physical environment to upgrade the living conditions of those plagued into these degraded areas. Lauder (2010) concurs with Acioly in that inner-city revitalisation includes everything from local economic development, enhanced urban design, to social policy programs and services for the contemporary city that is diverse and multicultural. Lauder (2010) though goes on to include the urban design as a means to revitalising the inner cities. If successful inner-city revitalisation is to be attained there is a need to improve the urban designs and this in my view is where ecological planning comes into the picture since it leads to the upliftment of the urban space thus contributing to urban sustainability if the design promotes and supports the local natural environment base. According to Zielenbach (2000) inner-city revitalisation is the physical redevelopment of blighted areas, creation of additional jobs, improvement of local infrastructure and or elimination of undesirable individuals and business. This is a radical approach and view of inner-city revitalisation argued by Zielenbach (2000) in that the elimination of undesirable individuals and businesses seem to be too harsh and gives room for some authorities to determine what has to be included and what has to be marginalised in the revitalisation process. The approach though gives credit to political influence in planning sphere though it assumes inner-city revitalisation is not people centered. For the purpose of this article the all-encompassing definition by Beauregard and Holcomb (1981) will be adopted who argue that inner-city revitalisation is investment to remodel or rebuild a portion of the urban environment to accommodate more profitable activities and expand opportunities for consumption, particularly retail and housing for middle- and upper- income households. Somehow the definition by Beauregard and Holcomb (1981) sheds more light on inner-city revitalisation as they asserts to the need to remodel or rebuild but it fails to explain how, thus it gives room for the inclusion of ecological planning initiatives revitalising the inner city.

From the table above, it can be observed that innercity revitalisation is a multi-faceted task that is initiated due to various reasons. The major reason for inner-city revitalisation that can be drawn according to Planning and Lands Bureau (2001) emerges as the need to restructure and re-plan designated areas by designing more effective and environmentally friendly local transport and road networks. Redevelopment of dilapidated buildings into new buildings of modern environmentally friendly standards is another objective that is also espoused in the Regional, Town and Country Planning Act (Sec 17) which points that inner-city revitalisation becomes necessary once the physical makeup of the city deteriorates or becomes obsolete. Pickard (2001) asserts to this point in that there is a need to protect and conserve the built and social composition in urban areas against threat posed by neglect, deliberate demolition and incongruous new construction.

Inner-city revitalisation seeks to transform the physical environment into a liveable space that is aesthetically pleasing and has no negative implications on the urban form. The natural environment is blended into the built space to create a benign environment. It can then be concluded that the major aim of inner-city revitalisation tend to be socio-spatial in that all efforts are directed at addressing issues to do with the physical condition of the infrastructure in the city. The condition of the infrastructure such as roads, houses and other structures tend to be central in inner-city revitalisation initiatives. Buildings have to be maintained in an attractive form to attract investment, thus transforming the area into a liveable space. Hermandez (2001) lucidly points out that the aim of neighbourhood revitalisation is to mend two characteristics of a neighbourhood; its social fabric and physical environment, without displacing the residents. From this viewpoint, inner-city revitalisation borrows much from the concept of sustainable development. Indeed, there is an inherent need to avoid displacing the residents in the given area and this shows that the process considers the well-being of the residents in the area, while also aiming to increase the economic base of the innercity as well as the natural and built environment.

The bottom line is there is no clear-cut, overarching explanation for inner-city revitalisation. It is a case of muddling through. Zielenbach (2000) describes the process as highly nuanced and at times downright messy, more of an art than a science. Zielenbach (2000) further notes that inner-city revitalisation requires a series of factors working in concert. Fainstein (1991, pp. 79) observe that as urban 
planners have become more directly involved in economic development, "market rationality and local competitiveness have replaced comprehensiveness and equity as the primary criteria by which planning projects are judged". It is clear from his argument that an economic approach is at times adopted in efforts to revitalize the inner cities due to the capitalistic nature of contemporary cities. This is a skewed approach to inner city revitalisation as an economic approach only considers market forces yet the aesthetics may also be of much importance when revitalising inner cities. It is at this stage that ecological planning comes at hand and attempts to embrace all the three dimensions of urban environments that culminate into sustainable development. Inner-city revitalisation may be executed through the development of the infrastructure in the area. It is a common belief that once the structural development is advanced this will automatically attract investors and business into the area as well as promoting accessibility through the development of viable road network systems. However, investors and business is not only attracted to such economically viable spaces. Some prefer an aesthetic outdoor environment; tree-lined street, parks for leisure. Hence, ecological planning presents opportunities that complement the economic efforts through possibly adopting green agenda ideals. Indicative planning is an approach to inner-city revitalisation that can be used at any planning level though it is widely recognised at national level. The spatiality of this approach ranges from local, district or regional level.

Balassa (1990) outlines indicative planning as a procedure that often seek to draw attention to the problems, indicate a broad direction for the solution and stimulate debate and discussion overcoming these problems, a debate in which numerous stakeholders get involved before workable policies are implemented. Compliance is usually not compulsory but rather planning incentives draw the attention of the developers and capitalise on these, therefore revitalising the designated areas. In some situations planning incentives such as building lines, bulk factor and rezoning may lure developers, investors and even encourage property owners to develop structures that are more profitable. For example rezoning a residential area into a mixed zone with offices and flats may be helpful since residential use is a low competitor in terms of returns on the land use. The provision of social services such as water supply, refuse collection and street lighting may appear as trivial issues but these actually contribute immensely in the success of revitalisation plans thus the need to consider this when revitalising the inner city. Thus, inner-city revitalisation may be achieved through the provision of adequate and reliable social services in the inner city. Indicative planning does not really conform to the concept of ecological planning. Ecological planning as discussed earlier on is founded on politics of an area, thus there has to be some directives from high above on the strategies for revitalisation. There has to be some compliance to say the use of solar power by households, in such a way a common goal is sought. Incentives are rather contextual and may fail to spur some interest in some individuals. Therefore, revitalisation plans are framed from citizen needs and what they feel is right for them without need for incentives, which often fail to achieve the required goals.

The government plays a significant role in inner-city revitalisation initiatives. Once the government (central or local) identifies a portion of the city in need of repair, it can go on to give directives and lead revitalisation plans to bring back sanity in such rundown areas. Section 35(1b) of the Regional, Town and Country Planning Act alludes to this point in that the Local Planning Authority can issue an enforcement order on the owner or occupier of the premises to develop the property in a given way. The government may proffer an enabling environment, direct development initiatives or come up with suggestions to the way forward in terms of revitalizing blighted areas. Porter (1997) argues that the government may create a favourable environment for businesses in the inner city. This may be achieved for example through upgrading infrastructure and streamlining regulations. Constrained budgets and financial standing of most local planning authorities often cripple them in terms of their mandates to revitalize inner cities. In such situations, the private sector may come in and collaborate with the government to execute revitalisation plans in cities. The public sector may offer technical and financial assistance to purchase land for expansion. Zielenbach (2000) simply advocates for the collaboration and partnership that should be established in planning efforts as the government often proves to be burdened with a plethora of financial mandates, thus the need to collaborate with the public sector. In other cases community based initiatives may be the key drive to inner-city revitalisation. Community members identify grey areas and take the leading role in revitalising their neighbourhoods. The communities know best what is good for them and have to make initiatives towards revitalisation of their neighbourhoods or they have to be actively involved in the process so that their concerns are integrated in the revitalisation plans. This refers to revitalisation initiatives starting at the grassroots levels with community members identifying what they desire and outlining their interests and values. Initiatives by governments are in most cases political and address the needs of only a fraction of the population. Not everyone's needs are addressed as there are always some personal interests in most cases. The other issue to consider is the costs involved in adopting ecological planning thus private sectors may be of much use in this regard. In the case of 
the inner city in Johannesburg, it emerges that collaboration with the private sector yield best results in revitalisation initiatives.

From the foregoing paragraphs, it has already emerged that there are five critical issues to note. First, the city is an ecosystem with natural, social, political and economic organisms and processes. Second, to achieve sustainability in inner-city revitalisation and from an ecological lens, interaction of the processes in the city ecosystem must be tapped, harnessed and capitalised upon. Third, conceptualisation and rethinking of the concept of sustainable development in cities through ecological planning and paradigms such as garden city, garden suburb and eco-cities is long overdue. Forth, the principal objective of inner-city revitalisation is the redress of physical decay in cities to increase the economic base for the city and its inhabitants. Fifth, multi-pronged approaches for inner-city revitalisation are required and often prove to have varying degrees of success, but the best method is full participation of all stakeholders taking into account a full detail and inventory of the socio-economic and environmental assets in the inner city. The next section will focus on the initiatives adopted by the city of Harare in attempts to revitalise the inner city.

\section{Initiatives in harare inner-city revitalisation}

The city of Salisbury (now Harare) was established on the $12^{\text {th }}$ of September 1890 by the British Pioneer column. The city is the oldest in the country and was widely referred to as the Sunshine City due to the effective and efficient management and outlook of the city at the time. Since the kopje offered a strategic location for security and close proximity to Mukuvisi River, it ultimately became the original site for the city of Harare. Further developments of the city occurred around this node. To date this area forms a significant part of the inner-city of Harare. There was no formal planning exercised during the early days of settling. The settlers were concentrated along the kopje. It was not until 1891 that the settlers undertook the first town planning exercise for the city of Harare. The plan consisted of a simple gridiron pattern with $400 \mathrm{~m}^{2}$ stands and $20 \mathrm{~m}$ wide roads. According to City of Harare (1988), much of the vegetation within the kopje, or rather that fell within the designated initial plan was cleared to pave way for development. The only vegetation that was spared is that found on the slopes of the kopje that comprise of various indigenous tree species and other plants. Due to the vast expanse of dense forests at the time, little attention was paid to the conservation of vegetation. The principles of ecological planning were not observed during this period as there was rampant clearing of forests that resulted in the area being transformed into a wholly built environment, with the kopje remaining as the only natural ecosystem, which stands to this day.
The economic turndown in the late 1990s resulted in the degradation of the once hailed city due to the manifestation of social ills, informality together with a stagnant development process. Various initiatives have been put at play trying to address the degraded state of the inner city. Past initiatives in seeking the transformation of the inner-city of Harare into a vibrant environment, have been futile. Socio-economic planning approaches adopted previously, had little effect on the face-lifting of the run down, and blighted inner-city of Harare (City of Harare 1988). Despite the continued employment of these initiatives by the city managers and planners, there has been little success to the revitalisation efforts in the city. Blighted areas continue to dominate the inner-city areas and the rate of total transformation has been snail-paced (Tekere1993).

\section{Special development order (for the Kopje Area), 1986}

The Kopje Area is part of the inner-city of Harare and was experiencing rapid decline due to declining economic base as investors and businesses were concentrating more on the emerging CBD around First Street. This resulted in physical deterioration of the environment, vacant buildings and irregular and illegal uses as noted by Tekere (1993). To address the ongoing deterioration the Special Development Order (Kopje Area) 1986 was operationalised as a revitalisation initiative. The city council engaged in the conversion of flats into offices and the eviction of residents as a way of doing away with the blight in the inner-city (City of Harare, 1988). In spite of these efforts, the desired results were not yielded as the residents failed to oblige due to speculation reasons. The revitalisation attempts failed to facelift the inner-city in that it paid little attention to the natural environment and instead focused more on the physical rubric of the area. The assumption was made that a conversion of the land use in the innercity would compel developers to revitalise the inner-city but that was not the case. An indicative planning approach was used at the time and as discussed earlier on it failed to yield the desired results by the city authorities.

\section{Local priority plan No. 17}

At times, the government (central or local), can take matters into its hands to facilitate and organise the revitalisation plans in a given area when the situation seem to have gone offhand. Section 35(1b) The Regional Town and Country Planning Act alludes to this point in that the Local Planning Authority can issue an enforcement order on the owner or occupier of the premises to develop the property in a given way. This gives a leeway for politicians to mastermind and influence the planning process and it is at this stage that planning often takes a twist and struggles to attain urban sustainability especially when these politicians advances their personal 
agendas. In the case of the Kopje area, the revitalisation of the inner-city was imminent. Thus, the government had to take the leading step in line with the Regional Town and Country Planning Act Section 17(3) (a) which calls for the preparation of such a plan by the Local Planning Authority for the redevelopment or improvement of land in an area requiring special consideration.

The Report of Study for the Kopje Market Square Area Local Priority Plan No. 17 indicates that the revitalisation plan was formulated after taking account of the inventory of the opportunities and constraints in the Kopje area was noted together with the constraints. Such a study was useful as it highlighted on the state of the existing infrastructure as well as the prevailing environmental conditions in the Kopje area. The revitalisation of the Kopje area was necessitated by the presence of old and dilapidated buildings together with unregulated and unauthorised uses in the area. There was a need to create an ideal environment that would uphold the Sunshine status of the city. Kopje Market Square Area Local Priority Plan No. 17's written statement notes that the revitalisation initiatives in the Kopje Area were to be achieved through the provision of business offices and shops, services and light industrial zone, suburban commercial complex, residential use component and a safe traffic and transport system. For the realisation of these objectives, the Local Authority was to play an active role and facilitate the revitalisation process of the Kopje area. From an analysis of the written statement on Local Plan No.17, the planning approach adopted for the revitalisation of the Kopje Area is largely inclined towards indicative planning which has a strong bias towards economic development. This planning approach concurs with Porter's ideal of the comparative advantage of the inner city, which seeks to revitalise the inner-city by capitalising on the opportunities of these areas. The approach focuses much on the development of a strong economic base that neglects the physical outlook of the area. Little regard was given to the natural resources in the area that was a cause for the failure of the plan by the City of Harare. Although these various planning incentives were at stake, they did little to convince developers and investors to revitalise the inner city, what was needed was a grand plan that would transform the environment to match the emerging office parks in the city. It can therefore be noted from the example that indicative planning or an economic planning for the city did little to enhance the natural environment which remained in its dilapidated state even after the formulation of the plan. This shows that, there is more to revitalisation than simply upgrading or addressing the local economic base of an area. Natural ecosystems have to be nested as well in the complex city setup to effect revitalisation efforts.
This approach by the government is more plausible and as noted by Van Dyk (2004), it mitigates and lessens market failure, as there will be an aspect of reinforcement that lacks in the indicative approach. The prescriptive or coordinated manner through which a city is run has always proved to have effective results as compared to a situation where there is no compulsion to develop in line with the government goals and policies. The indicative planning approach in the Kopje has failed to deliver the intended results. This is due to the fact of the absence of capacity to establish the economic base in the area upon which businesses would be able to grow and develop. This has been the major reason why the area has failed to attract much investment as investors and developers do not see any incentive for developing in the area. The Local Priority Plan No. 17 sought to revitalise the inner-city through a combination of socioeconomic factors. The local authority emphasised the need to provide social services region. They argued that once the social services were upgraded it would ultimately lead to successful inner-city revitalisation. Planning incentives promised to potential investors, developers and property owners' fall under economic planning which was used as a strategy to lure these various stakeholders to develop in the inner-city thus increasing the economic base thus sustaining revitalisation initiatives. Although the city of Harare wishes to attain economic growth and attract investment back into the inner city, there is an inherent need to rethink ecological planning which forms the lifeblood of the inner-city thus ensuring that the revitalisation initiatives for the city are realised successfully. Although an economic base was in existence in the Kopje area, the physical environment remained in a sorry state. Revitalisation efforts should have tapped on the environment as well so that there was an incorporation of the natural environment into the revitalisation plan rather than just maintaining the kopje in its original state. The inclusion of parks and more greenery would have had been a worthwhile investment. One other initiative that was used to revitalise the inner-city about Local Priority Plan No. 17 was the introduction of mixed land use. Residential component has been preserved and industrial, commercial, industrial and institutional uses have been incorporated in the Kopje to promote the revitalisation of the area through the complementary of the land uses. This aspect of mixed land use concurs with UN-HABITAT (2009) wherein such an approach has been called for in the revitalisation of inner cities.

The period has not been specified in that the rate of development is rather influenced by the ability and willingness of the developers to develop their properties. There has been no time limit set for the achievement of the revitalisation goals in that it becomes difficult to predict a timeframe or period in which the developers will 
develop or improve their properties. That being the case, it then becomes necessary to let events occur without determination of time. The plan will only be superseded by another one once new opportunities and constraints will be identified previously not accounted for. This is in conflict with the successful revitalisation of the inner-city in Johannesburg were the time was pegged at 30 years and the plan had to be reviewed. It gives the council and the developers a sense of urgency as there will be a target that has to be met. Therefore, this has been a flaw of the revitalisation of the Kopje area in Harare.

\section{Present: Vision 2025 and other initiatives}

The City of Harare Strategic Plan 2012-2025 is the current plan among many formulated by the city council in their attempts to bring back life and vibrancy to the once thriving city (City of Harare, 2012). The vision 2025 espoused by the city of Harare in 2012 aims at bringing back sanity to the city and restore city's Sunshine status (see Figure 1). This involves greening the central part of the town, an initiative that sounds rather too romanticised against the background of macro-economic sustainability in the country. Besides, the city council has been criticised heavily for bad 'caretakership' of the city attributed to corruption and financial mismanagement. This has seen the following negative developments: continued collapse of general service delivery, heavily potholed roads, inconsistent water delivery in 60 percent of the suburbs of the city, poor waste management and general refuse collection, late payment of most junior employees since 2009, and the bloated structure of council having 13 directors as of January 2014 (The Zimbabwean, 2014). Harare's grandiose dream, against this background, then sounds more of a pipedream than anything (cf. Chirisa et al. (2014); Kawadza, 2014).

It can be observed from the strategic plan that the objectives are to provide adequate social services in the form of roads, water, health and schools. The belief is that the provision of such services will ultimately culminate in the

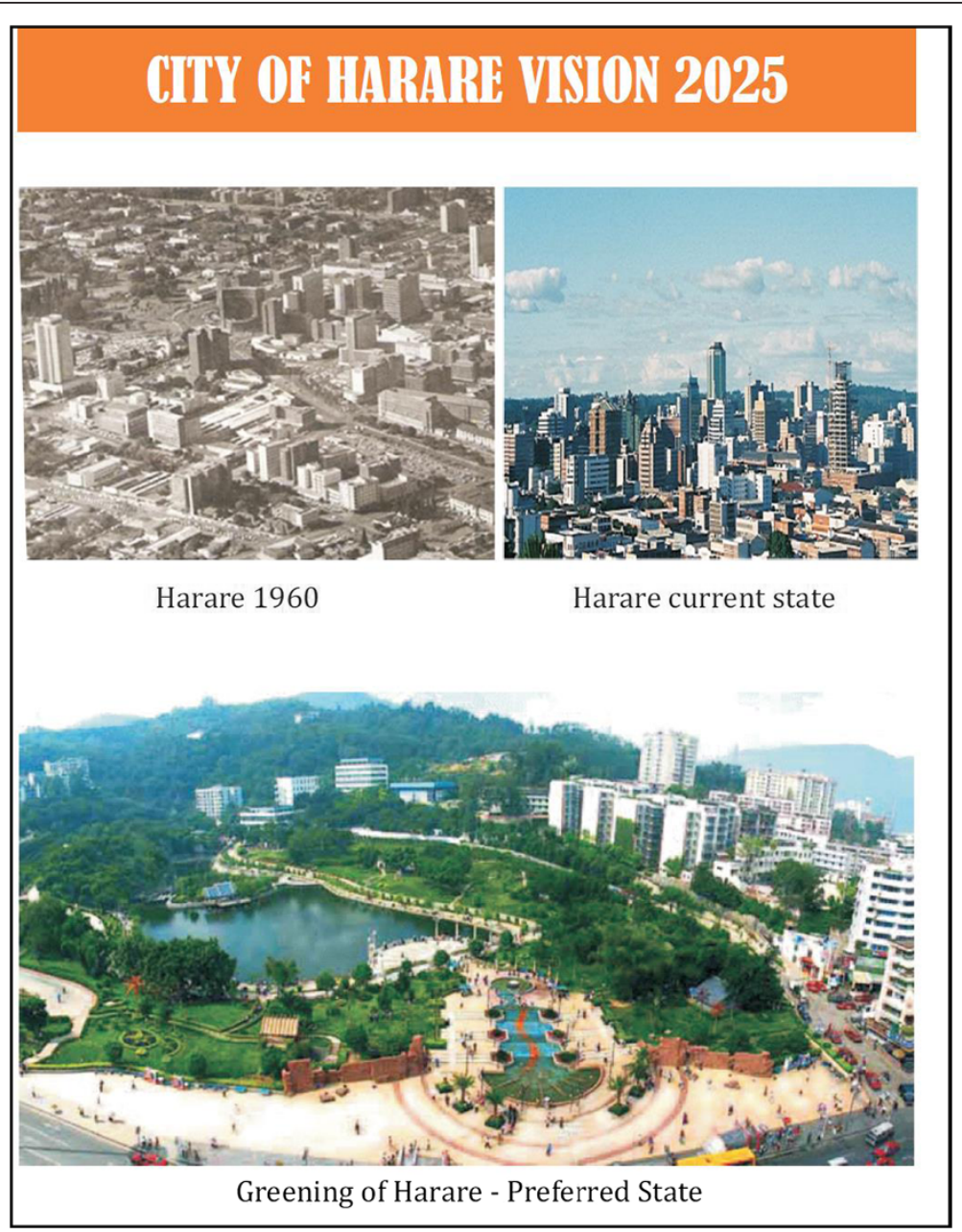

Figure 1 Harare's Dream. 
successful revitalisation of the city and inner-city as people will be attracted to the social services. The transformation of the urban form through application of densification and information and communication technology as a management tool is another initiative to be used to revitalise the city and create the excellent city. In addition to this solar energy harvesting and bio-fuel production also emerge as initiatives to revitalise the city of Harare. Such are the initiatives that have been lacking for the city if it is ever to transform physically. Most planners and urban designers of this age aim for the use of solar energy at reducing greenhouse gas emission thereby maintaining a low-carbon city, which is envisioned. This is all in pursuit of creating a world class city which impacts positively on the environment. The document acknowledges the risk of climate change and its impact on the city's physical infrastructure. Efforts are made to reduce the greenhouse gas emissions in the city by desisting from the use of toxic and non-renewable energy sources that tend to increase carbon emission. This current plan attempts to upgrade and maintain a natural environment in the city to levels that result in reduction of pollution, conservation and preservation of flora and fauna while supporting the socio-economic well-being of the city. Above all the strategic plan aims at promoting safe environmental health practices through partnerships and ultimately results in a beautiful and sustainable outdoor urban environment that can be classified as a world-class city. The partnerships with various stakeholders is a good initiative which has been hailed as the key factor in revitalising inner cities especially considering the financial constrains that riddle local authorities.

Although the Vision 2025 may seem noble, more has to be done to attain the intended goals and planned objectives. The planning initiatives are rather disentangled and rarely exist as one. There seem to be a piece meal and fragmented approach to the planning initiatives in Zimbabwe often addressed at specific sectors thus leaving a lot of gaps which have to be filled to attain urban sustainability in Harare. Zimbabwe is currently bedevilled by a plethora of financial challenges and the introduction of information and communication technology is very costly and affects negatively on the city's budget. This may result in the abortion of the strategy in its infancy stage thus failure to realise the intended goals. The vision also calls much upon the engagement of private sector to revitalise the city. The engagement of the private sector is in line with the Green Agenda, which encourages the inclusion of various stakeholders in urban development. However, this may lead to a disjuncture from the city vision due to differences in values and interests between the city managers, developers, and property owners.

\section{Discussion}

The foregoing paragraphs suggest that past efforts to revitalise the inner-city of Harare have been futile. A successful story cannot be narrated with regards the revitalisation issue, approaches adopted tend to be irrelevant and inappropriate towards revitalising the inner city. However, there is much potential and room for realising and retelling a positive story if the ecological concept to planning is embraced as a strategy to revitalise the inner-city of Harare. Investors, residents and property owners are not compelled to develop due to planning incentives in most cases. The need to work and reside in an aesthetically pleasing environment drives stakeholders into an area. In light of the arguments posited by Howard (1902), it becomes noble to integrate aspects of the country in the city. This has the qualities of cleansing the city, which is associated with many psychological effects on the citizens. The recent emergence and preference of office parks in Harare bear testimony to this fact ecological planning has to be at the core of city revitalisation while all other factors then come into play. A city being an ecosystem has to consider all the various elements and processes within it as well as the stakeholders and players therein. The inner-city revitalisation plan and strategy thus need to integrate aspects of the natural environment such as tree-lined streets, roof gardens, solar powered traffic lights and use of non-toxic energy sources.

\section{Lessons from theory and practice}

Six lessons can be drawn from the forgoing discourse. First, inner-city revitalisation requires the engagement of stakeholders at all levels in a given locality. It needs not be exclusionary. The citizens, property owners as well as investors often help to outline their values and interests that crystallise into the broad revitalisation plan therefore sustaining development. Second, timeframes are critical when it comes to revitalisation initiatives as these provide investors and developers as well as the council with a sense of urgency and act with deadlines. Third, critical to note is that the city is a complex ecosystem with various organisms within it hence the need to model it holistically taking into account the various processes that culminate from the processes and their interaction so as to attain sustainable inner-city revitalisation. Next, the integration of vegetation into the city helps to reduce carbon emission and promote the quality of the environment through cleansing of the atmosphere thus helping in the pursuit of low carbon cities. In addition, people appreciate an urban space that exhibits the characteristics of the natural physical environment such as tree-lined streets, open spaces with plants as well as roof gardens. This is associated with stress relief and other 
health and psychological benefits. Last, inner-city revitalisation plans require an element of compulsion wherein the council forces the investors, developers and property owners to develop in a certain manner. If people are not compelled they tend to relax or engage in developments that do not conform to city council's plans.

\section{Conclusion and recommendations}

In conclusion, past approaches to revitalise the innercity in Harare have proved to have many flaws, as there are archaic and fail to address inner-city revitalisation comprehensively. In this instance, pockets of urban decay remain despite the formulation of revitalisation plans. The previous approaches are more relaxed in that they do not consider the city as an ecosystem and neglect ecological planning issues; rather they focus more on socio-economic issues and the number of players involved has been limited thus the results have not been so favourable. Therefore, a strategic approach is required for inner-city revitalisation focusing on ecological planning wherein the physical environment is greatly altered bringing in aspects of the country and natural environment. Prescriptive and coordinated means can also be sought to compel investors and developers to development and contribute to the revitalisation of the inner city. For Harare, we suggest the following measures in keeping with the lessons highlighted above:

- Adopt prescriptive planning approach in which the key players or developers and property owners are compelled to develop in line with city council goals and aspirations.

- Engage all stakeholders in the revitalisation plans. Embrace full participation wherein all members of the community contribute and give their views and interests.

- Set time-frames to revitalisation plans which should be evaluated and monitored on a regular basis to make sure those events on the ground tally with council's plans within the specified period.

- Integrate ecological planning in revitalisation plans so that every organism in the city's complex system is addressed and integrated into the revitalisation plans.

- Promote a green revolution in the city by communicating with the developers, investors and property owners so that they become conscious of the benefits of ecological planning and its mandates, this can even be achieved by setting by laws that promote the concepts of ecological planning.

- Establish greening at the household and individual plot level $t$ with green buildings, automatically this builds to neighbourhood and eventually the city's vision will be successfully realised by 2025 .
Competing interests

The authors declare that they have no competing interests.

\section{Authors' contributions}

AM suggested the idea of writing an article on inner-city revitalisation. IC developed the idea and together AM and IC developed the paper, engaging literature and talking to key informants. Both authors read and approved the final manuscript.

\section{Author details}

${ }^{1}$ Centre for Applied Social Sciences, University of Zimbabwe, PO Box MP167, Mt Pleasant, Harare, Zimbabwe. ²Department of Rural \& Urban Planning, University of Zimbabwe, PO Box MP167, Mt Pleasant, Harare, Zimbabwe.

Received: 22 August 2014 Accepted: 4 November 2014

Published online: 10 December 2014

\section{References}

Acioly CC (1999) Institutional and Urban Management Instruments for Inner-city Revitalisation: a brief review with special focus on Brazilian experiences. Draft working paper 1999, IHS, Rotterdam

Bakker S, Laginja I, Željezić A (2005) Manual Green Agenda in Croatia: Theory and Practice. Milieukontokt Oost-Europa, Amsterdam

Balassa B (1990) Indicative Planning in Developing Countries. The World Bank, Washington

Beauregard RA, Holcomb HB (1981) Revitalising Cities. Association of American Geographers, Washington

Bright EM (2000) Reviving America's Forgotten Neighbourhoods: An Investigation of Inner City Revitalization Efforts. Garland Publishing: New York \& London

Campbell S (1996) Green cities, growing cities, just cities? Urban planning and the contradictions of sustainable development. J Am Plan Assoc 62(3):296-312

Chirisa I (2010) Inner-City Revitalisation and the Poor in Harare: Experiences, Instruments and Lessons from Mbare', Chapter 6 in Urbanising Africa: the city centre revisited Experiences with inner-city revitalisation from Johannesburg (South Africa), Mbabane (Swaziland), Lusaka (Zambia), Harare and Bulawayo (Zimbabwe). Institute for Housing and Urban Development Studies, Rotterdam

Chirisa I, Kawadza S, Muzenda A (2014) Unexplored Elasticity of Planning and Good Governance in Harare, Zimbabwe. Int Rev Spatial Plann Sustainable Dev 2(4):19-29

City of Harare (1988) Kopje/Market Square Area-Local Priority Plan No. 17: Draft Written Statement. Dept of Works, Harare, City of Harare

City of Harare (2012) City of Harare Strategic Plan 2012 - 2025. City of Harare, Harare

Fainstein S (1991) Promoting economic development: urban planning in the United States and Great Britain'. J Am Plan Assoc 57:22-33

Felson AJ, Pickett STA (2005) Designed experiments: new approaches to studying urban ecosystems. Frontiers. Ecol Environ 3:549-556

Freestone R (2006) Reinterpreting The Garden City Concept. Chinese Planning Network, Beijing

Government of Zimbabwe (2009) Short Term Emergency Recovery Programme (Sterp): Getting Zimbabwe Moving Again. Government of Zimbabwe, Harare

Government of Zimbabwe (2013) Zimbabwe Agenda for Sustainable SocioEconomic Transformation (Zim-Asset): "Towards an Empowered Society and a Growing Economy". Government of Zimbabwe, Harare

Hammer S, Kamal-Chaoui L, Robert A, Plouin M (2011) Cities and Green Growth: A Conceptual Framework', OECD Regional Development Working Papers, no. 2011/08. OECD Publishing, Paris

Hardoy EJ, Mitlin D, Satterwaite D (1993) Environmental Problems in Third World cities. Earthscan, London

Hermandez MM (2001) Impact of commercial development on inner-city revitalization: an analysis of projects in Boston. Unpublished Masters Thesis. Massachusetts Institute of Technology, Department of Urban Studies and Planning

Howard E (1902) Garden Cities of Tomorrow. Faber and Faber, London

Hutchings A (2011) Garden suburbs in Latin America: a new fieldof international research? Plan Perspect 26(2):313-317

Kawadza S (2014) Vision 2025: Will Harare Make it? The Herald, 13 February 2014. Zimpapers, Harare 
Kjellén M, McGranahan G (2006) Informal Water Vendors and the Urban Poor. Human Settlements Discussion Paper Series Theme: Water-3. IIED, London, http://www.iied.org/pubs/pdf/full/10529llED.pdf

Latham A (2000) Urban renewal, heritage planning and the remaking of an inner-city suburb: a case study of heritage planning in Auckland, New Zealand. Plan Pract Res 15(4):285-298

Lauder C (2010) Downtown Revitalisation Strategies in Ontario's Mid-sized Cities: a Web Survey Case Study, Masters of Arts Thesis. University of Waterloo, Waterloo

Lethaby WR, Purdom CB (1921) Town Theory and Practice. Benn Brothers, London

McHarg IL (1981) Human ecological planning at Pennsylvania. Landscape Plann 8 (2):109-120

Nicholson-Lord D (2003) Green Cities - And Why We Need Them. New Economics Foundation, London

Pickard R (ed) (2001) Management of Historic Centres. SPON Press, London Planning and Lands Bureau (2001) People-First- A caring Approach to Urban Renewal: Urban Renewal Strategy. Urban Renewal Unit Planning and Lands Bureau, Hong Kong

Porter M (1997) New strategies for inner-city economic development. Econ Dev Q 11:1

Ross CL, Leigh NG (2000) Planning, Urban revitalisation, and the inner city: an exploration of structural racism. J Plan Lit 14:367

Rusong W (1996) Human-ecological approach to sustainable urban development, Towards a sustainable city. Methods of urban ecological planning and its application in Tianjin, China. UNESCO, Paris

Steiner FR (2002) Human Ecology: Following Nature's Lead. Island Press, Washington, DC

Swilling M (2005) Sustainability and infrastructure planning in South Africa: A Cape Town case study. Environ Urbanisation 18:1

Tekere ABC (1993) Redevelopment of the Harare Kopje Area', Chapter 11. In: Zinyama LM Tevera D, Cumming S (eds) Harare: The Growth and Problems of the City. University of Zimbabwe, Harare

The Zimbabwea (2014) The City of Harare Should be saved from Vultures., URL: http://www.thezimbabwean.co/news/zimbabwe-news/70301/the-cityof-harare-should.html. Accessed on 20 May 2014

UN-HABITAT (2009) Planning Sustainable Cities: Global Report on Human Settlements 2009. Earthscan, London

UN-HABITAT (2010) African Cities Driving the NEPAD Initiative: An Introduction to the NEPAD Cities Programme, African Ministerial Conference on Housing and Urban Development(AMCHUD). UN-HABITAT, Nairobi

United Nations Environmental Programme (2007) Liveable Cities. The Benefits of Urban Environmental Planning: A Cities Alliance Study on Good Practices and Useful Tools. The Cities Alliance, Washington

Van Dyk MP (2004) Opportunities for Urban Management in Emerging Economies. Renmin University Press, Renmin

White T, Silberman LW, Anderson PR (1948) Nairobi Master Plan for a Colonial Capital. His Majesty's Stationery Office, Nairobi City Council: Nairobi

Williams RA (2000) Environmental Planning for Sustainable Urban Development, Paper presented at the Caribbean Water and Wastewater Association Conference \& Exhibition, 2 - 6 October 2000. Trinidad

World Commission on Environment and Development (1987) Our Common Future, World Commission on Environment and Development (the Brundtland Commission). Press, Oxford University

World Health Organisation (WHO) (2002) Reducing Risks. Promoting Healthy Life, Geneva

Zielenbach S (2000) Art of Revitalisation: Improving Conditions in Distressed Inner-city Neighbourhoods. Garland Science Publishing, New York

doi:10.1186/s40410-014-0014-1

Cite this article as: Matamanda and Chirisa: Ecological planning as an inner-city revitalisation agenda for Harare, Zimbabwe. City, Territory and Architecture 2014 1:14

\section{Submit your manuscript to a SpringerOpen ${ }^{\odot}$ journal and benefit from:}

- Convenient online submission

- Rigorous peer review

- Immediate publication on acceptance

- Open access: articles freely available online

- High visibility within the field

- Retaining the copyright to your article

Submit your next manuscript at $\gg$ springeropen.com 